Kinestetik : Jurnal Ilmiah Pendidikan Jasmani 5 (3) (2021)

Kinestetik : Jurnal Ilmiah Pendidikan Jasmani

https://ejournal.unib.ac.id/index.php/kinestetik/index

DOI : 10.33369/jk.v5i3.17028

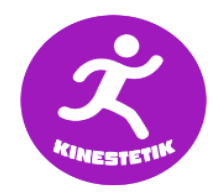

\title{
IMPLEMENTATION OF PJOK LEARNING DURING THE COVID-19 PANDEMIC BETWEEN PUBLIC SCHOOLS AND \\ PRIVATE ELEMENTARY SCHOOLS IN REJANG LEBONG REGENCY
}

Defliyanto $^{1}$, Tono Sugihartono ${ }^{2}$, Edwin Hariansyah ${ }^{3}$,

${ }^{123}$ Physical Education, Universitas Bengkulu, Bengkulu, Indonesia

\section{Article Info \\ Article History : \\ Received : August 2021 \\ Revised : September 2021 \\ Accepted : September 2021 \\ Available online : September 2021}

\section{Keywords:}

Learning, application, corner

\begin{abstract}
This study aims to to find out the application of learning and the differences in the application of PJOK learning during the Covid-19 pandemic which was carried out by State and Private Schools at the SD level throughout Rejang Lebong Regency. This type of research is descriptive qualitative. The subjects of this study amounted to 60 people consisting of the Principal, Teachers and Students. The instruments and data collection techniques used in this study were observation, questionnaires, interviews and documentation. The data analysis technique used is descriptive analysis with percentages. The results showed that the implementation of PJOK learning during the Covid-19 pandemic related to the Semester Program, RPP and Learning Process at State Elementary Schools was in the Good category with a percentage of 70\%, the Ministry of Education's Private Elementary School was in the Very Good category with a percentage of $81.66 \%$, and Private Elementary Schools. The Ministry of Religion is in the Enough category with a percentage of 59\%. Furthermore, the difference in the application of learning in public schools and private schools lies in the learning methods and media used by each elementary school unit.
\end{abstract}

\footnotetext{
Corresponding address : Jl. Raden Fatah No.13 Kota Bengkulu

*Corresponding email : Defliyanto@unib.ac.id

ISSN 2685-6514 (Online)

ISSN 2477-331X (Print)
} 


\section{INTRODUCTION}

Education in Indonesia is currently undergoing a transition period in the process of implementing the learning provided to students. This is because learning activities that were previously carried out directly in the classroom must now switch to distance or online learning activities. This situation is caused by the Covid-19 pandemic which will still occur until 2021. The distance learning activities are applied to all subjects in each educational unit, including sports subjects whose learning activities must be carried out remotely.

Conditions that have not returned to normal have caused the learning process at all levels of education to carry out distance learning (PJJ) in order to stop the spread of the virus. This indeed makes it a challenge for academics and educators to continue to provide lessons to students by using advances in existing technology. However, in implementing distance learning activities, educators sometimes experience obstacles in the process of giving lessons because of the lack of understanding of educators on the use of modern technology, especially in elementary schools, this has caused some PJOK teachers to experience obstacles or obstacles during the online learning process in the midst of the Covid-19 pandemic. Nopiyanto, 2020).

The process of distance learning activities in elementary schools is not only felt by public schools, but also private schools. However, it is not yet known exactly how the learning implementation is carried out in public and private schools during the current Covid-19 pandemic, due to the different locations and conditions experienced by schools. Due to the different conditions and status of public and private schools, of course there are some gaps that occur such as human resources (HR), then the learning methods used by each school, as well as the differences in the facilities that support learning activities owned by each school greatly affect the smooth and success in implementing learning during the Covid19 Pandemic.

Learning carried out by educational units, both public and private, during the current Covid-19 pandemic, makes schools and educators have to create a new learning system in implementing PJOK learning both in terms of learning programs or in the process of implementing their activities. This is done so that teaching and learning activities continue to run as it should, but to realize it certainly educators must be professional in developing and using learning technologies to date (Raibowo et al., 2019)

Based on the exposure of the problems that have been described makes researchers interested in conducting activities research related to "Implementation of PJOK Learning in the Covid-19 Pandemic Period between Public Schools and Private Schools at the Elementary Level in Rejang Lebong Regency

\section{METHODS}

Based on the problems and research objectives that have been discussed previously, the method used in the research "Implementation of PJOK Learning in the Middle Ages The Covid-19 Pandemic Between Public Schools and Private Elementary Schools in Rejang Lebong Regency, namely with a qualitative descriptive method. According to Sugiyono (2016) descriptive research is the method used by researchers to conduct research on a subject, or a system of thought, events experienced now and the status of human groups. This descriptive study aims to describe systematically and accurately the facts, relationships or characteristics between the phenomena 
being investigated. The place and time of this research was carried out in all public elementary schools that have A accreditation and all private elementary schools under the auspices of the Ministry of Education and Culture and the Ministry of Religion in Rejang Lebong Regency from 23 February to 23 March 2021. The subjects of this study were 60 people from 20 Schools which include the Principal, PJOK Teachers and Students.

Table 1. Research Subjects

\begin{tabular}{|c|c|c|}
\hline \multicolumn{3}{|c|}{ School } \\
\hline No & Public & Private \\
\hline 1 & 10 Principals & 10 Principals \\
\hline 2 & $\begin{array}{l}10 \text { Teachers } \\
\text { PJOK }\end{array}$ & 10 Teachers PJOK \\
\hline 3 & 10 Students & 10 Students \\
\hline & $\mathrm{al}=30$ People & Total $=30$ People \\
\hline \multicolumn{3}{|c|}{ Total Total $=60$ People The } \\
\hline
\end{tabular}

data collection technique in this study used observation, questionnaires, interviews and documentation, while the instrument used in this research is a learning application questionnaire that has been in Expert Judgment and validated by experts.

The data analysis technique carried out on the data that has been obtained is by analyzing the data in the field using the Miles and Huberman model in the form of data reduction, data display, and the last is conclusion/verification activities. And by using the percentage formula as follows: The formula used is (Sudjana, 2011)

Table 2. CategorizationNorma

\begin{tabular}{ccc}
\hline NO & Value Range & Category \\
\hline 1 & $81 \%-100 \%$ & Very Good \\
\hline 2 & $61 \%-80 \%$ & Good \\
\hline 3 & $41 \%-60 \%$ & Adequate \\
\hline 4 & $21 \%-40 \%$ & Not Good \\
\hline 5 & $0 \%-20 \%$ & $\begin{array}{c}\text { Very Not } \\
\text { Good }\end{array}$ \\
\hline
\end{tabular}

\section{RESULTS}

Based on the overall results of the implementation of PJOK learning in Public and Private schools under the auspices of the Ministry of Education and Culture and the Ministry of Religion, it can be concluded that in the application of PJOK learning during the Covid-19 Pandemic, State Elementary Schools are in the category of "Good" learning implementation with a percentage of $70 \%$.

Private elementary schools under the auspices of the Ministry of Education and Culture are in the category of "very good" learning implementation with a percentage of $81.66 \%$. Meanwhile, private elementary schools under the auspices of the Ministry of Religion are in the "Enough" learning application category with a percentage of $59 \%$.

Implementation of PJOK Learning in Public Elementary Schools and Private Elementary Schools During the Covid-19 Pandemic

This study aims to determine the application of PJOK learning during the Covid-19 pandemic between public and private schools at the elementary level in Rejang Lebong Regency. The results of the implementation of PJOK learning on the Semester Program indicators carried out by the principals of public elementary schools are in the "Good" category with a percentage of $60 \%$. Meanwhile, private elementary school principals under the auspices of the Ministry of Education and Culture are in the "Very Good" category with a percentage of $80 \%$. However, private elementary school principals under the auspices of the Ministry of Religion are in the "Enough" category with a percentage of $60 \%$. The results of implementing PJOK learning on the Semester Program indicators carried out by PJOK teachers at State Elementary Schools are in the "Good" category with a 
percentage of $60 \%$. Meanwhile, private elementary school PJOK teachers under the auspices of the Ministry of Education and Culture are in the "Good" category with a percentage of $60 \%$. However, private SD PJOK teachers under the auspices of the Ministry of Religion are in the "Enough" category with a percentage of $60 \%$. The results of implementing PJOK learning on Semester Program indicators carried out by State Elementary School students are in the "Good" category with a percentage of $80 \%$. Meanwhile, private elementary students under the auspices of the Ministry of Education and Culture are in the "Good" category with a percentage of $60 \%$. However, private elementary school students under the auspices of the Ministry of Religion are in the "Enough" category with a percentage of $60 \%$.

It is very important that the semester program is structured as well as possible because it contains an outline of the learning activities to be carried out during one semester (Bastary et al., 2018). So that in preparing the semester program, the foresight of educators is needed and practical training is needed to produce the right semester program (Astuti, 2018). Based on the results of the semester program indicators in the implementation of learning carried out by public schools and private schools under the auspices of the Ministry of Education and Culture, it has been well implemented, but in private schools under the auspices of the Ministry of Religion, there is still a need for roles between all educators and the government, then the government still needs encouragement and attention to can help improve the application of learning in the Private Elementary School. This of course aims to make schools able to implement better learning and be able to develop semester programs that will be carried out more optimally.

The results of the implementation of PJOK learning on the RPP indicators carried out by the principals of State Elementary Schools are in the "Good" category with a percentage of $70 \%$. Meanwhile, private elementary school principals under the auspices of the Ministry of Education and Culture are in the "Good" category with a percentage of $60 \%$. However, private elementary school principals under the auspices of the Ministry of Religion are in the "Enough" category with a percentage of $80 \%$. The results of the implementation of PJOK learning on the RPP indicators carried out by PJOK teachers in SD Negeri are in the "Good" category with a percentage of $70 \%$. Meanwhile, private elementary school PJOK teachers under the auspices of the Ministry of Education and Culture are in the "Very Good" category with a percentage of $60 \%$. However, private SD PJOK teachers under the auspices of the Ministry of Religion are in the "Enough" category with a percentage of $80 \%$. The results of implementing PJOK learning on RPP indicators carried out by State Elementary School students are in the "Good" category with a percentage of $70 \%$. Meanwhile, private elementary students under the auspices of the Ministry of Education and Culture are in the "Good" category with a percentage of $60 \%$. However, private elementary school students under the auspices of the Ministry of Religion are in the "Enough" category with a percentage of $80 \%$.

Based on the results of the RPP indicators above, the implementation of learning carried out by public schools and private schools under the auspices of the Ministry of Education and Culture has been well implemented, this is of course in line with what Astawa (2019) stated, that RPP is a form of mandatory curriculum development. compiled by each teacher and used as a guide in carrying out learning activities. So that in compiling the RPP the teacher must consider the characteristics of students, learning objectives, teaching and 
learning activities and learning materials (Susetya, 2017). However, in private schools under the auspices of the Ministry of Religion, training and direction provided by the government is still very much needed, so that schools can better prepare lesson plans that will be taught to students, this is of course aimed at making schools able to achieve the goals of the desired learning activities.

The results of the implementation of PJOK learning on the indicators of the Learning Process carried out by the principal of the State Elementary School are in the "Good" category with a percentage of $70 \%$. Meanwhile, private elementary school principals under the auspices of the Ministry of Education and Culture are in the "Very Good" category with a percentage of $60 \%$. However, for private elementary school principals under the auspices of the Ministry of Religion, learning is in the "Enough" category with a percentage of $60 \%$. The results of implementing PJOK learning on the indicators of the Learning Process carried out by PJOK teachers in State Elementary Schools are in the "Good" category with a percentage of $70 \%$. Meanwhile, private elementary school PJOK teachers under the auspices of the Ministry of Education and Culture are in the "Very Good" category with a percentage of $60 \%$. However, private elementary schools under the auspices of the Ministry of Religion are in the "Enough" category with a percentage of $60 \%$. The results of implementing PJOK learning on the indicators of the Learning Process carried out by State Elementary School students are in the "Good" category with a percentage of $70 \%$. Meanwhile, private elementary students under the auspices of the Ministry of Education and Culture are in the "Good" category with a percentage of $60 \%$. However, private elementary school students under the auspices of the
Ministry of Religion are in the "Enough" category with a percentage of $60 \%$.

Based on the results of the learning process indicators above, the implementation of the learning process in public schools is good and private schools under the auspices of the Ministry of Education and Culture are very good. This is of course supported by relevant research conducted by Anggraeni \& Akbar (2018) where the learning process and lesson plans are a unified whole where it is a strategy and obligation that must be carried out by educators in order to be able to direct students to understand the learning material that has been taught. well delivered. This of course can be done by carrying out the learning process through assistance with observation techniques, clinical discussions and workshops (Nurhamidah et al., 2014). In addition, during the pandemic it is highly recommended to combine face-to-face classes with online classes (Nopiyanto et al., 2021). The goal is that activities carried out during the Covid-19 pandemic continue to run smoothly and are able to achieve the goals of learning optimally, but there are differences with the results of research conducted by Raibowo \& Nopiyanto (2020), regarding the teaching and learning process of PJOK in Bengkulu City during the period The Covid-19 pandemic is in the low category with a percentage of $79.59 \%$. So that private schools under the auspices of the Ministry of Religion still need guidance and training provided by the government so that schools understand how to properly implement the process of learning activities that will be carried out in the midst of the Covid-19 pandemic, this aims so that the essence of learning activities can be carried out more effectively. .

Analysis of the data that has been carried out above, overall it can be concluded that in the implementation of PJOK learning during the Covid-19 
pandemic related to Semester Program indicators, RPP, and Learning Processes at State Elementary Schools are categorized as "Good" with a percentage of $70 \%$, then For Private Elementary Schools under the auspices of the Ministry of Education and Culture as a whole in the implementation of PJOK learning during the Covid-19 pandemic, it was categorized as "Very Good" with a percentage of $81.66 \%$. However, for Private Elementary Schools under the auspices of the Ministry of Religion as a whole, the implementation of PJOK learning during the Covid-19 pandemic was categorized as "Enough" with a percentage of $59 \%$. Based on these results, it is in line with the relevant research conducted by Herlina (2020), the results of the research that have been carried out are known that PJOK learning activities have the potential to be developed during the Covid-19 pandemic using a collaborative approach. This is of course in line with the results of research conducted by Rezky (2020), where the teacher's efforts to improve thematic learning in elementary schools during the Covid-19 pandemic is by delivering learning carried out by a teacher. So that there are new opportunities for academics to develop PJOK learning methods that will be carried out during the Covid-19 pandemic (Kurniawan, 2020).

Differences in the Implementation of Learning in Public Elementary Schools and Private Elementary Schools During the Covid-19 Pandemic. Overall

data analysis that has been carried out can be seen that there are differences in the application of learning carried out by each school where the main difference lies in the methods and media used in during learning activities in the midst of the Covid-19 pandemic. This learning media can be understood as anything that can be used to stimulate thoughts, feelings, attention, and will so that it can encourage the learning process in students. The use of learning media will make learning activities run more interesting because it makes students curious about what material is contained in the media (Raibowo et al., 2020). Offline and online learning methods are a way that is used to support each other in achieving basic competencies in learning in accordance with the curriculum (Solong, 2021). Online and offline learning methods applied by schools certainly have a goal, namely teachers are expected to always be creative in educating students, so that learning success can be achieved properly and more effectively (Pratama \& Mulyati, 2020).

State schools implement learning activities using online and offline methods, as well as using learning media in the form of videos andapplication assistance in the online form of Whatsapp Groups as a means of distributing learning materials and assignments. The combination of online and offline learning methods has proven to be effective during the Covid-19 pandemic (Nopiyanto et al., 2021). Furthermore, in private schools under the auspices of the Ministry of Education and Culture, the application of learning is carried out using Offline and online methods, but tends to carry out more offline learning activities, and uses learning media in the form of videos andapplication assistance online such as Whatsapp Groups and Zoom Meetings which are used as a means of delivering material, assignments and discussions during online learning activities. As for private schools under the auspices of the Ministry of Religion, the method used is only offline/face-to-face, so there is nolearning media online used by the school. 


\section{CONCLUSION}

Based on the results of the research and discussion that have been put forward, a conclusion can be drawn, namely:

1. The application of PJOK learning during the Covid-19 pandemic related to Semester Programs, Learning Implementation Plans (RPP) and Learning Processes, it is known that State Elementary Schools are categorized as "Good" with a percentage of $70 \%$. Then private elementary schools under the auspices of the Ministry of Education and Culture are in the "Very Good" category with a percentage of 81.66\%. However, private elementary schools under the auspices of the Ministry of Religion are in the "Enough" category with a percentage of $59 \%$.

2. The difference in the application of PJOK learning during the Covid-19 pandemic between public and private elementary schools throughout Rejang Lebong Regency, lies in the methods and learning media used. Public and Private Schools under the auspices of the Ministry of Education and Culture use online and offline learning methods, as well as using learning media in the form of videos andapplications online such as Whatsapp Groups, but at the Ministry of Education and Culture Private Elementary Schools using an additional application, namely Zoom Meeting. Meanwhile, for private schools under the auspices of the Ministry of Religion, the learning methods used are offline/face-to-face only, so there is nolearning media online used by schools.

\section{REFERENCES}

Anggraeni.,\& Akbar, A. (2018). Conformity of the Learning Implementation Plan and the Learning Process. Journal of Basic Enchantment, 6(2), 55-65.

Arikunto. (2012). Categorization Norms. Earth Literature.

Astawa, IBM (2019). Understanding the Obligations of Teachers in Developing Learning Implementation Plans. Journal of Chemical Information and Modeling, 53(9), 1689-1699.

Astuti, DS (2018). Analysis of Difficulties in Compiling Annual Programs and Semester Programs for Prospective Teachers. 58-62.

Bastary, R., Moroki, ESG, Yunaidi, YY, Priyono, S., \& Iswoyo, S. (2018). Management Module 2013 Curriculum Implementation for Elementary School. Directorate General of Teachers and Education Personnel.

Herlina. (2020). Learning Potential of PJOK in the Midst of the COVID-19 Pandemic Journal of Sport Sciences And Physical Education, 8, 7.

Kurniawan, MTA (2020). Review Article: Impact of the Covid-19 Pandemic on Education in Indonesia. National Seminar \& Conference ..., 111-117.

Nopiyanto, YE (2020). Barriers to Physical Education Teachers in the 80s Generation in online learning in the midst of the COVID-19 pandemic. 5(September), 139-148.

Nurhamidah, S., Dantes, N., \& Lasmawan, W. (2014). Efforts to Improve Management of the Learning Process Through Assistance in the 2013 Curriculum for Class I and IV Teachers. Ganesha's Journal of Basic Education, 4(1), 123510. 
Pratama, RE, \& Mulyati, S. (2020). Online and Offline Learning during the Covid-19 Pandemic. 1(2), 49-59.

Raibowo, S., Adi, S., \& Hariadi, I. (2020). Effectiveness and Feasibility Test of Field Tennis Teaching Materials Based on Interactive Multimedia. 944-952.

Raibowo, S., \& Nopiyanto, YE (2020). PJOK's Teaching and Learning Process during the COVID-19 Pandemic. 1, 112-119.

Raibowo, S., Nopiyanto, YE, \& Muna, MK (2019). PJOK Teachers' Understanding of PJOK Professional Competency Standards. 2(1), 10-15.

Rezky, ZA (2020). Teachers' Efforts in Improving Learning Activities in Elementary School Thematic Learning During the COVID-19 Pandemic. 21(1), 1-9.

Solong, NP (2021). Offline and Online Learning Management. 9, 19-32.

Sugiyono. (2016). RESEARCH METHODS. Alphabet.

Susetya, Benny. (2017). Improving Teacher Ability in Compiling Syllabus and Lesson Plans. 01(02), 1-27. 